\title{
FAPA mass spectrometry of hydroxychalcones. Comparative studies with classical methods of ionization
}

\author{
Marek Smoluch ${ }^{1 *}$, Grazyna BartKowiak ${ }^{2}$, Edward ReszKe ${ }^{3}$, \\ WojCiech LechowicZ ${ }^{4}$, Jerzy SilberRING ${ }^{1,5}$, GrZEgorz Schroeder ${ }^{2}$ \\ ${ }^{1}$ AGH University of Science and Technology, Department of Biochemistry and Neurobiology, Faculty of Materials Science \\ 2 Adam Mickiewicz University in Poznań, Faculty of Chemistry, Umultowska 89b, 61-614 Poznan, Poland \\ ${ }^{5}$ Centre of Polymer and Carbon Materials, Polish Academy of Sciences, Curie-Sklodowskiej 34, 41-819 Zabrze, Poland
} and Ceramics, Mickiewicza 30, 30-059 Cracow, Poland

${ }^{3}$ ERTEC-Poland, Rogowska 146/5, 54-440 Wroclaw, Poland

${ }^{4}$ Institute of Forensic Research, Westerplatte 9, 31-033 Cracow, Poland

\begin{tabular}{|c|c|}
\hline ARTICLE INFO & ABSTRACT \\
\hline $\begin{array}{l}\text { Received } 13 \text { February } 2014 \\
\text { Accepted } 07 \text { March } 2014\end{array}$ & $\begin{array}{l}\text { In this paper we are focused on analysis of hydroxychalcones, i.e. 2'-hydroxychalcone, } \\
\text { 3'-hydroxychalcone and 4'-hydroxychalcone, by the Flowing Atmospheric Pressure }\end{array}$ \\
\hline $\begin{array}{l}\text { Keywords: } \\
\text { FAPA, } \\
\text { mass spectrometry, } \\
\text { hydroxychalcones. }\end{array}$ & $\begin{array}{l}\text { Afterglow mass spectrometry (FAPA-MS), and on comparison of the obtained data with } \\
\text { other classical methods including ESI-MS, APCI, MALDI, and GC/EI-MS. The paper } \\
\text { is presenting fragmentation pathways of both positive-, and negative hydroxychalcone } \\
\text { ions. Tested compounds were characterized by comparison of the results (signals } \mathrm{m} / \mathrm{z} \\
\text { and relative intensities) from the five mass spectrometry techniques, showing very good } \\
\text { utility of FAPA method for fast and easy analysis of the low molecular weight compounds. } \\
\text { Moreover, FAPA does not require a time-consuming derivatization, nor search for a } \\
\text { suitable solvent or matrix, often incompatible with various ion sources. }\end{array}$ \\
\hline
\end{tabular}

\section{INTRODUCTION}

Chalcones are a group of compounds belonging to the flavonoid family. Chemically, using IUPAC nomenclature, they are 1,3-diphenyl-2-propen-1-ones. Chalcones comprise of an important class of natural products, which have been reported to possess a wide spectrum of biological activities, including anti-bacterial [1], anti-viral, insect anti-feedant, anti-mutagenic [2], anti-fungal [3], anti-inflammatory, anticancer [4], anti-ulcer, spasmolytic [5], and antiproliferative [6]. Such features make chalcones a very interesting class of compounds with therapeutic potential, and therefore interesting for scientific investigation and robust analysis.

Chalcones and their derivatives have been analyzed by several mass spectrometry methods, such as MALDI, ESI, $\mathrm{APCI}$ and GC/EI-MS. In this paper we were focused on the analysis of hydroxychalcones (Fig.1) by a Flowing Atmospheric Pressure Afterglow mass spectrometry (FAPA) [7]. To our best knowledge, chalcone analysis by FAPA has not been reported yet. The advantages of FAPA analysis over other methods are: simplicity of sample preparation and

\section{Corresponding author}

* e-mail:smoluch@agh.edu.pl rapid analysis by direct nebulization and introduction into the FAPA source.

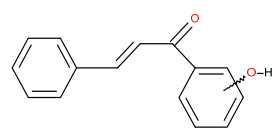

Figure 1. A core structure of hydroxychalcones studied. Hydroxy group is located at ortho (2' -hydroxychalcone), (2'-OH-Ch); meta (3' -hydroxychalcone), (3'-OH-Ch) or para (4' -hydroxchalcone), (4'-OH-Ch) position of ring $\mathrm{B}$

\section{EXPERIMENTAL}

\section{Chemicals}

Methanol (HPLC gradient grade, J.T. Baker, The Netherlands) was used for hydroxychalcones dissolution in all methods used, except GC-MS where chloroform (SigmaAldrich, Poznan, Poland) was applied. MALDI matrices, i.e. sinapinic acid (SA) and 2.5-dihydroxybenzoic acid (DHB) were purchased from Sigma-Aldrich (Poznan, Poland).

\section{FAPA measurements}

A prototypic NOVA011 (ERTEC, Wrocław, Poland) flowing atmospheric-pressure afterglow (FAPA) plasma 
source was used for the ionization of hydroxychalcones. The FAPA source was described elsewhere [8]. Briefly, the outlet of the FAPA source was mounted approximately $1 \mathrm{~cm}$ from the inlet of a mass spectrometer at horizontal position. The helium discharge gas was continuously delivered at a flow rate of $1.0 \mathrm{~L} / \mathrm{min}$. The small portable nebulizer was used for all sample injectons. The final concentration of measured samples was $0.1 \mathrm{mg} / \mathrm{mL}$ and the volume of sample injection by nebulization was $10 \mu \mathrm{L}$. A Bruker Esquire 3000 quadrupole ion trap mass spectrometer (Bruker Daltonics, Bremen, Germany) was used for all measurements with the same settings as for ESI source, with the exception of the capillary voltage where a much lower potential $(1 \mathrm{kV})$ than in the standard ESI settings $(4.5 \mathrm{kV})$ was used.

\section{ESI measurements}

The standard ESI ion source was used and was installed in the Esquire 3000 quadrupole ion trap mass spectrometer (Bruker Daltonics, Bremen, Germany). The samples $(0.1 \mathrm{mg} / \mathrm{mL}$ in methanol) were infused with the aid of syringe pump (Harvard Apparatus infusion pump, US) at a flow rate of $5 \mu \mathrm{l} / \mathrm{min}$. The scan range was $m / z=50-500$, with 10 psi nebulizer gas, $6 \mathrm{~L} / \mathrm{min}$. dry gas, and heated capillary adjusted to $300 \mathrm{C}$. Tandem MS experiments were carried out in the manual fragmentation mode with fragmentation amplitude of $1.00 \mathrm{~V}$.

\section{APCI measurements}

The APCI mass spectra were obtained using a Quattro Micro API triple quadrupole mass spectrometer (Waters/ Micromass, Manchester, UK). The samples were applied with an in-built syringe pump at a flow rate of $30 \mu \mathrm{l} / \mathrm{min}$. The scan range was $\mathrm{m} / \mathrm{z}=50-300$, with Corona current of $8 \mu \mathrm{A}$, Cone voltage was set to $15 \mathrm{~V}$, Extractor voltage was $5 \mathrm{~V}$, and source temperature $130 \mathrm{C}$, desolvation temperature was maintained at 300C. Argon was used as a collision gas for MS/MS experiments. In this case the following parameters were set as follows: cone voltage $30 \mathrm{~V}$, extractor $10 \mathrm{~V}$ and collision energy $30 \mathrm{eV}$.

\section{MALDI measurements}

The MALDI mass spectra were obtained on a hybrid instrument, Q-TOF Premier mass spectrometer (Waters/ Micromass, Manchester, UK) under control of the MassLynx V4.1 software, equipped with a $200 \mathrm{~Hz}$ repetition rate $\mathrm{Nd} / \mathrm{YAG}$ laser $\left(\lambda=355 \mathrm{~nm}\right.$, power density $\left.107 \mathrm{~W} / \mathrm{cm}^{2}\right)$. In order to prepare the target spots, the methanolic solution containing matrix $\left(1 \mu \mathrm{l}\right.$, concentration $\left.0.5 \mathrm{~mol} / \mathrm{dm}^{3}\right)$ has been deposited on the spot and allowed to dry at room temperature. After a few minutes, $1 \mu \mathrm{L}$ of solution containing chalcone derivatives (ca $1 \mathrm{mmol} / \mathrm{dm}^{3}$ ) were placed as a next layer over the dried matrix and left to cocrystallize. The MALDI-MS/MS spectra were obtained on the same instrument. Argon was used as a collision gas at a flow rate of $0.5 \mathrm{~mL} / \mathrm{min}$. Collision energies (CEs) for MS/MS were set at $10 ; 20 ; 30$, and $40 \mathrm{eV}$, depending on the experiments.

\section{GC-MS measurements}

GC-MS spectra were obtained on the Varian GC CP3800 gas chromatograph with a VF-5ms, $30 \mathrm{~m} \times 0.25 \mathrm{~mm}$ ID column (Varian Part No. CP8944). The following settings were used: temperature program $40-280^{\circ} \mathrm{C}$, ramp $\left[15^{\circ} \mathrm{C} / \mathrm{min}\right]$, carrier gas Helium $(1 \mathrm{~mL} / \mathrm{min}$. $)$, injector Type 1177 , split $1: 50$, temperature $220^{\circ} \mathrm{C}$, detector 4000 MS (temperature: trap $180^{\circ} \mathrm{C}$, manifold $50^{\circ} \mathrm{C}$, transfer line $220^{\circ} \mathrm{C}$ ), ionization mode: EI (Internal), $70 \mathrm{eV}$, sample volume: $1 \mu \mathrm{L}$, solvent: chloroform, mass range $40-400 \mathrm{~m} / \mathrm{z}$.

\section{RESULTS AND DISCUSSION}

Ion sources for mass spectrometry are vital parts of instrumentation, as their construction implies types of the compounds to be analyzed, their mass range, way of linking with various separation techniques, compatibility with solvents, and general conditions for analysis. For electrospray ionization, chromatographic separation or at least SPE purification step should be implemented before sample introduction into the instrument, whereas GC technique demands derivatization in most cases. In contrast to the above-mentioned techniques, atmospheric-pressure glow discharge (APGD), and its modified version, the flowing atmospheric-pressure afterglow (FAPA), allows for fast and simple identification without or with little sample preparation $[8,9]$.

In order to compare the quality of the information (molecular/pseudomolecular ions, fragmentation patterns) obtained from the FAPA spectra and amount of preparative handling, the model group of compounds, hydroxychalcones were selected.

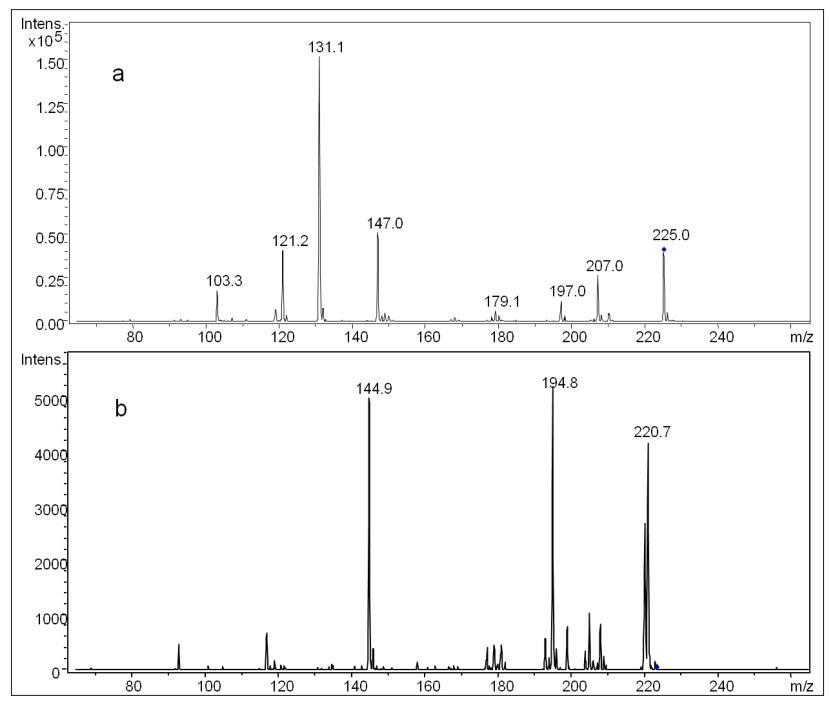

Figure 2. The FAPA-MS/MS spectra of 4'-OH-Ch in the positive (a) and negative (b) modes

To compare fragmentation patterns of hydroxychalcones among mass spectrometry techniques, MS/MS experiments were performed for both negative and positive ions. The recorded MS/MS signals are shown in Table 1. Examplary MS/MS spectra are shown in Fig. 2 for 4'-OH-Ch isomer. 
Table 1. FAPA-MS/MS ions for isomers of hydroxychalcones. $\%$ RA denotes relative abundance. The base peak in bold.

\begin{tabular}{|c|c|c|c|}
\hline & $2^{\prime}-\mathrm{OH}-\mathrm{Ch}$ & 3'-OH-Ch & 4'-OH-Ch \\
\hline & $m / z(\%$ R.A $)$ & $m / z$ (\% R.A) & $m / z(\%$ R.A) \\
\hline \multicolumn{4}{|c|}{ Positive ion mode } \\
\hline$[\mathrm{M}+\mathrm{H}]^{+}$ & 225 (19) & $225(23)$ & $225(26)$ \\
\hline$\left[\mathrm{M}+\mathrm{H}-\mathrm{CH}_{3}\right]^{+}$ & $210(100)$ & $210(17)$ & $210(0)$ \\
\hline$\left[\mathrm{M}+\mathrm{H}-\mathrm{H}_{2} \mathrm{O}\right]^{+}$ & $207(15)$ & $207(33)$ & $207(18)$ \\
\hline$[\mathrm{M}+\mathrm{H}-\mathrm{CO}]^{+}$ & $197(5)$ & & $197(8)$ \\
\hline$\left[\mathrm{M}+\mathrm{H}-\mathrm{CO}-\mathrm{H}_{2} \mathrm{O}\right]^{+}$ & $179(14)$ & $179(4)$ & $179(3)$ \\
\hline $\mathrm{C}_{9} \mathrm{H}_{7} \mathrm{O}_{2}^{+}$ & $147(15)$ & $147(66)$ & $147(33)$ \\
\hline $\mathrm{C}_{9} \mathrm{H}_{7} \mathrm{O}^{+}$ & $131(16)$ & $131(100)$ & $131(100)$ \\
\hline $\mathrm{C}_{7} \mathrm{H}_{5} \mathrm{O}_{2}^{+}$ & $121(41)$ & & $121(28)$ \\
\hline $\mathrm{C}_{7} \mathrm{H}_{3} \mathrm{O}_{2}^{+}$ & & $119(23)$ & \\
\hline $\mathrm{C}_{8} \mathrm{H}_{7}^{+}$ & & $103(13)$ & $103(11)$ \\
\hline \multicolumn{4}{|c|}{ Negative ion mode } \\
\hline$\left[\mathrm{M}-\mathrm{H}-\mathrm{H}_{2}\right]^{-}$ & $221(44)$ & $221(53)$ & $221(80)$ \\
\hline$\left[\mathrm{M}-\mathrm{H}-\mathrm{H}_{2} \mathrm{O}\right]^{-}$ & $205(22)$ & & \\
\hline$[\mathrm{M}-\mathrm{H}-\mathrm{CO}]^{-}$ & $195(100)$ & $195(66)$ & $195(100)$ \\
\hline $\mathrm{C}_{9} \mathrm{H}_{5} \mathrm{O}_{2}^{-}$ & $145(2)$ & $145(100)$ & $145(96)$ \\
\hline $\mathrm{C}_{6} \mathrm{H}_{5} \mathrm{O}^{-}$ & $93(4)$ & & $93(8)$ \\
\hline
\end{tabular}

Data shown in Table 1 also include relative abundances (\% RA) of the fragment ions as they are important to distinguish isomers. Isomer ortho can easily be distinguished. In a positive ion mode this compound produces a very intense fragment at $m / z 210$, which is not present for the para-compound and is barely visible in the background for meta-isomer. The negative ion mode signal at $m / z 145$ is not significant for the ortho- isomer, while it comprises a major peak for other isomers. These observations are also consistent with other ionization methods later discussed in this paper. The suggested explanation for differences in fragmentation between isomers is due to the fact that intramolecular hydrogen bond is formed (Fig. 3) for the ortho- compound, what makes deprotonation of $\mathrm{OH}$ group more difficult.

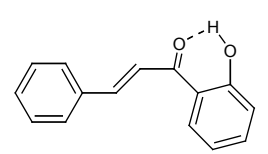

Figure 3. Intramolecular hydrogen bond formation for orthohydroxychalcone causes differences in fragmentation patterns between isomers (meta and para)

A more challenging task is to distinguish between isomers meta and para. There are some differences in MS/MS spectra for both compounds, such as removal of CO group observed in the positive ion mode signal at $\mathrm{m} / z 197$ or 195 in the negative ion mode, but the differences are not obvious. The proposed structures of fragment ions obtained during FAPA-MS/MS analysis are shown in Figures 4 and 5.

To compare fragmentation patterns between ionization techniques, all isomers of hydroxychalcones were also analyzed by ESI-MS (data not shown) and ESI-MS/MS technique (example in Fig. 6).

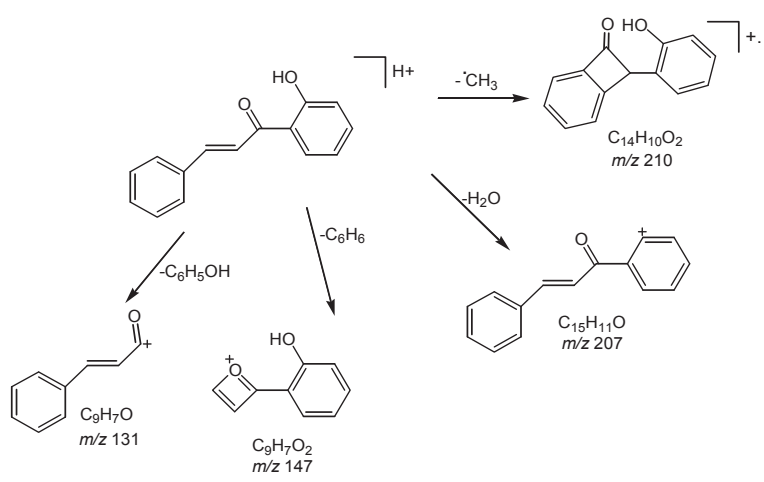

Figure 4. Proposed structures of MS/MS fragment ions in the positive ion mode (based on the ref. 10, where ESI technique was used). Fragment at $m / z 210$ is a major peak for ortho-compound and almost not visible for other isomers

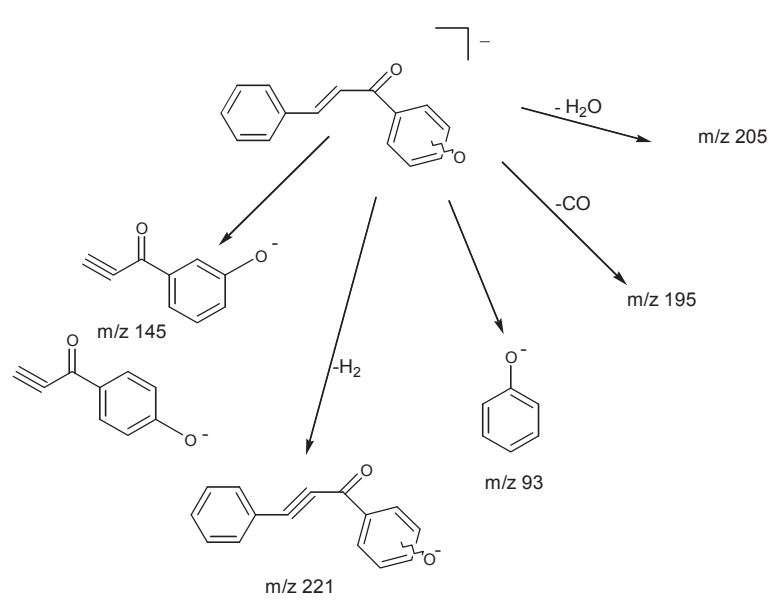

Figure 5. Proposed structures of MS/MS fragment ions in the negative ion mode. Fragment at $\mathrm{m} / \mathrm{z} 145$ for ortho-hydroxychalcone is not significant (see text for detailed explanation)

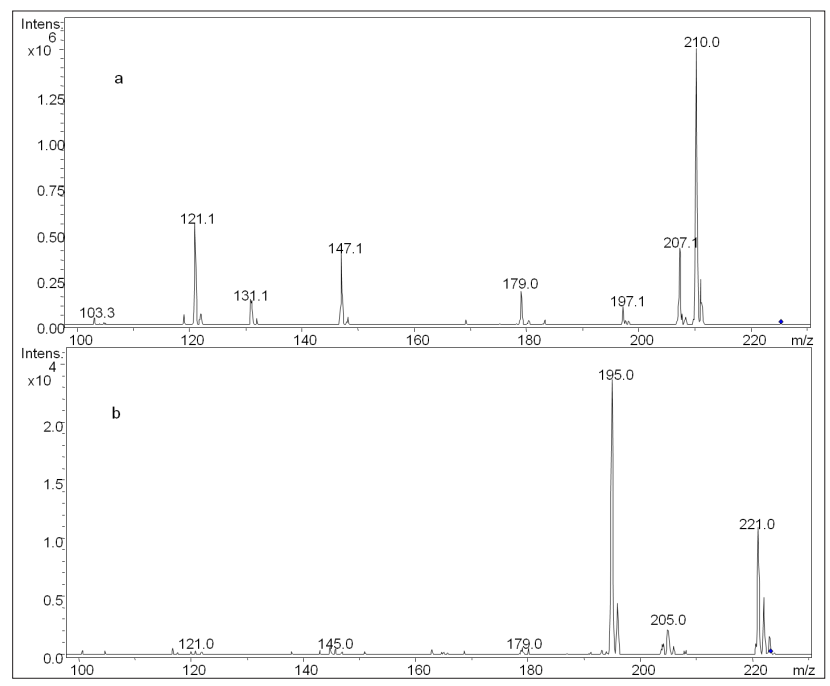

Figure 6. The ESI-MS/MS spectra of 2'-OH-Ch in the positive (a) and negative (b) ion modes 
The obtained information characterizing the spectra, $\mathrm{m} / \mathrm{z}$ values, and the relative ion intensities were the same for FAPA and ESI ionizations. Almost identical series of MS/ MS fragments are observed, including similar ion abundances for all hydroxychalcone isomers (Table 2). The data for 2'-OH-Ch isomer are also available in the literature [11], where ESI-MS and ESI-MS/MS experiments were performed. The data are consistent with those obtained in our experiments.

Table 2. Comparative data of MS/MS spectra FAPA and ESI for the most interesting ions

\begin{tabular}{|c|c|c|c|c|c|c|}
\hline & \multicolumn{2}{|c|}{$2^{\prime}-\mathrm{OH}-\mathrm{Ch}$} & \multicolumn{2}{|c|}{$3^{\prime}-\mathrm{OH}-\mathrm{Ch}$} & \multicolumn{2}{|c|}{ 4'-OH-Ch } \\
\hline & FAPA & ESI & FAPA & ESI & FAPA & ESI \\
\hline & \multicolumn{6}{|c|}{$m / z$ (\% R.A) } \\
\hline & \multicolumn{6}{|c|}{ positive ion mode } \\
\hline$\left[\mathrm{M}+\mathrm{H}-\mathrm{CH}_{3}\right]^{+}$. & $210(100)$ & $210(100)$ & $210(17)$ & $210(15)$ & & \\
\hline$[\mathrm{M}+\mathrm{H}-\mathrm{CO}]^{+}$ & $197(5)$ & $197(8)$ & $197(57)$ & $197(6)$ & $197(8)$ & $197(2)$ \\
\hline$\left[\mathrm{M}+\mathrm{H}-\mathrm{CO}-\mathrm{H}_{2} \mathrm{O}\right]^{+}$ & $179(14)$ & $179(13)$ & $179(4)$ & $179(59)$ & $179(3)$ & $179(5)$ \\
\hline $\mathrm{C}_{9} \mathrm{H}_{7} \mathrm{O}_{2}^{+}$ & $147(15)$ & $147(26)$ & $147(66)$ & $147(69)$ & $147(33)$ & $147(32)$ \\
\hline $\mathrm{C}_{9} \mathrm{H}_{7} \mathrm{O}^{+}$ & $131(16)$ & $131(9)$ & $131(100)$ & $131(100)$ & $131(100)$ & $131(100)$ \\
\hline \multicolumn{7}{|c|}{ negative ion mode } \\
\hline$[\mathrm{M}-\mathrm{H}-\mathrm{CO}]^{-}$ & $195(100)$ & $195(100)$ & $195(66)$ & $195(59)$ & $195(100)$ & $195(100)$ \\
\hline $\mathrm{C}_{9} \mathrm{H}_{5} \mathrm{O}_{2}^{-}$ & $145(2)$ & $145(3)$ & $145(100)$ & $145(100)$ & $145(96)$ & $145(67)$ \\
\hline
\end{tabular}

The analysis of hydroxychalcones by APCI brought quite different results compared to those obtained by FAPA. The main differences were observed for analyses performed in the negative ion mode. In this case, more ions are visible for APCI ionization. In the positive ion mode more similarities are seen, although intensities of particular ions markedly differ between both techniques. The data comparison (APCI vs. FAPA) is shown in Table 3.

Table 3. Comparative data of MS/MS spectra FAPA and APCI for the most intense ions. Ion abundances in parentheses

\begin{tabular}{|c|c|c|c|c|c|c|}
\hline & \multicolumn{2}{|c|}{ 2'-OH-Ch } & \multicolumn{2}{|c|}{$3^{\prime}-\mathrm{OH}-\mathrm{Ch}$} & \multicolumn{2}{|c|}{$4^{\prime}-\mathrm{OH}-\mathrm{Ch}$} \\
\hline & FAPA & APCI & FAPA & APCI & FAPA & APCl \\
\hline & \multicolumn{6}{|c|}{$m / z$ (\% R.A) } \\
\hline & \multicolumn{6}{|c|}{ positive ion mode } \\
\hline$\left[\mathrm{M}+\mathrm{H}-\mathrm{CH}_{3}\right]^{+}$ & $210(100)$ & $210(21)$ & $210(17)$ & & & \\
\hline$[\mathrm{M}+\mathrm{H}-\mathrm{CO}]^{+}$ & $197(5)$ & & $197(57)$ & & $197(8)$ & \\
\hline $\mathrm{C}_{9} \mathrm{H}_{7} \mathrm{O}_{2}^{+}$ & $147(15)$ & $147(4)$ & $147(66)$ & $147(6)$ & $147(33)$ & $147(11)$ \\
\hline $\mathrm{C}_{9} \mathrm{H}_{7} \mathrm{O}^{+}$ & $131(16)$ & $131(28)$ & $131(100)$ & $131(100)$ & $131(100)$ & $131(100)$ \\
\hline $\mathrm{C}_{7} \mathrm{H}_{5} \mathrm{O}_{2}^{+}$ & $121(41)$ & $121(100)$ & & $121(11)$ & $121(28)$ & $121(59)$ \\
\hline \multicolumn{7}{|c|}{ negative ion mode } \\
\hline$\left[\mathrm{M}-\mathrm{H}-\mathrm{H}_{2}\right]^{-}$ & $221(44)$ & & $221(53)$ & & $221(80)$ & \\
\hline$[\mathrm{M}-\mathrm{H}-\mathrm{CO}]^{-}$ & $195(100)$ & $195(91)$ & $195(66)$ & $195(34)$ & $195(100)$ & \\
\hline \multirow[t]{2}{*}{$\mathrm{C}_{9} \mathrm{H}_{5} \mathrm{O}_{2}^{-}$} & $145(2)$ & $145(20)$ & $145(100)$ & $145(100)$ & $145(96)$ & \\
\hline & & \begin{tabular}{|c|}
$193(65)$ \\
$147(35)$ \\
$117(23)$ \\
$101(39)$ \\
$77(22)$
\end{tabular} & & \begin{tabular}{|c|}
$193(35)$ \\
$117(34)$ \\
$101(7)$ \\
$91(72)$ \\
$77(10)$ \\
\end{tabular} & & \begin{tabular}{|l|}
$119(27)$ \\
$117(28)$ \\
$91(100)$
\end{tabular} \\
\hline
\end{tabular}

\section{MALDI-MS}

All isomers of hydroxychalcones were analyzed by MALDI-TOF with two matrices: DHB and SA. Both matrices used in the study gave good and comparable results. The observed signals are protonated species. In contrary to ESI and FAPA-MS, dimers with sodium and potassium adducts were observed (data not shown). Fragmentation patterns for all isomers in the positive and negative ion modes differ from that obtained by ESI and FAPA (Table 4). The main difference is the lack of ions at $\mathrm{m} / \mathrm{z} 197$ and 207 corresponding to the loss of $\mathrm{CO}$ and $\mathrm{H}_{2} \mathrm{O}$, respectively. It seems that MALDI-TOF technique causes simultaneous loss of both $\mathrm{CO}$ and $\mathrm{H}_{2} \mathrm{O}$ neutrals, what is confirmed by the presence of ion at $m / z 179$.

Table 4. Comparative data of MS/MS spectra FAPA and MALDI TOF (SA matrix)

\begin{tabular}{|c|c|c|c|c|c|c|}
\hline & \multicolumn{2}{|c|}{ 2'-OH-Ch } & \multicolumn{2}{|c|}{ 3'-OH-Ch } & \multicolumn{2}{|c|}{$4^{\prime}-\mathrm{OH}-\mathrm{Ch}$} \\
\hline & FAPA & MALDI & FAPA & MALDI & FAPA & MALDI \\
\hline & \multicolumn{6}{|c|}{$m / z$ (\% R.A) } \\
\hline & \multicolumn{6}{|c|}{ positive ion mode } \\
\hline$[\mathrm{M}+\mathrm{H}]^{+}$ & 225 (19) & $225(100)$ & $225(23)$ & $225(95)$ & $225(26)$ & 225 (95) \\
\hline$\left[\mathrm{M}+\mathrm{H}-\mathrm{CH}_{3}\right]^{+}$ & $210(100)$ & $210(30)$ & $210(17)$ & $210(45)$ & & \\
\hline$\left[\mathrm{M}+\mathrm{H}-\mathrm{H}_{2} \mathrm{O}\right]^{+}$ & $207(15)$ & & $207(33)$ & & $207(18)$ & $207(10)$ \\
\hline$[\mathrm{M}+\mathrm{H}-\mathrm{CO}]^{+}$ & $197(5)$ & & $197(57)$ & & $197(8)$ & \\
\hline$\left[\mathrm{M}+\mathrm{H}-\mathrm{CO}-\mathrm{H}_{2} \mathrm{O}\right]^{+}$ & $179(14)$ & $179(20)$ & $179(4)$ & $179(45)$ & $179(3)$ & $179(6)$ \\
\hline $\mathrm{C}_{9} \mathrm{H}_{7} \mathrm{O}_{2}^{+}$ & $147(15)$ & $147(15)$ & $147(66)$ & & $147(33)$ & $147(11)$ \\
\hline $\mathrm{C}_{9} \mathrm{H}_{7} \mathrm{O}^{+}$ & $131(16)$ & $131(20)$ & $131(100)$ & $131(100)$ & $131(100)$ & \\
\hline $\mathrm{C}_{7} \mathrm{H}_{5} \mathrm{O}_{2}^{+}$ & $121(41)$ & $121(75)$ & & $121(40)$ & $121(28)$ & $121(30)$ \\
\hline $\mathrm{C}_{7} \mathrm{H}_{3} \mathrm{O}_{2}^{+}$ & & & $119(23)$ & & & \\
\hline \multirow[t]{2}{*}{$\mathrm{C}_{8} \mathrm{H}_{7}^{+}$} & & & $103(13)$ & & $103(11)$ & $103(8)$ \\
\hline & \multicolumn{6}{|c|}{ negative ion mode } \\
\hline$[\mathrm{M}-\mathrm{H}]^{-}$ & & $223(45)$ & & $223(95)$ & & $223(100)$ \\
\hline$\left[\mathrm{M}-\mathrm{H}-\mathrm{H}_{2}\right]^{-}$ & $221(44)$ & $221(12)$ & $221(53)$ & & $221(80)$ & \\
\hline$\left[\mathrm{M}-\mathrm{H}-\mathrm{H}_{2} \mathrm{O}\right]^{-}$ & $205(22)$ & $205(8)$ & $205(3)$ & & $205(22)$ & \\
\hline$[\mathrm{M}-\mathrm{H}-\mathrm{CO}]^{-}$ & $195(100)$ & $195(100)$ & $195(66)$ & $195(100)$ & $195(100)$ & $195(5)$ \\
\hline$\left[\mathrm{M}-\mathrm{H}-\mathrm{CO}-\mathrm{H}_{2} \mathrm{O}\right]^{-}$ & $177(3)$ & 177 traces & & & & \\
\hline $\mathrm{C}_{9} \mathrm{H}_{5} \mathrm{O}_{2}^{-}$ & $145(2)$ & $145(9)$ & $145(100)$ & $145(70)$ & $145(96)$ & \\
\hline $\mathrm{C}_{6} \mathrm{H}_{5} \mathrm{O}^{-}$ & $93(4)$ & $93(35)$ & & $93(70)$ & $93(8)$ & $93(20)$ \\
\hline
\end{tabular}

\section{GC-EI MS}

We have measured EI spectra for the three isomeric hydroxychalcones by GC/EI-MS. The results are shown in Table 5, while Fig. 7 presents mass spectra of all separated chalcones obtained by this technique.

Table 5. EI MS ion mode fragmentation ions for isomers of hydroxychalcones

\begin{tabular}{|c|c|c|c|c|}
\hline \multirow{2}{*}{$\begin{array}{l}\text { ion } \\
m / z\end{array}$} & \multirow{2}{*}{$\begin{array}{l}\text { Proposed ion structure } \\
\text { or origin }\end{array}$} & $2^{\prime}-\mathrm{OH}-\mathrm{Ch}$ & $3^{\prime}-\mathrm{OH}-\mathrm{Ch}$ & $4^{\prime}-\mathrm{OH}-\mathrm{Ch}$ \\
\hline & & \multicolumn{3}{|c|}{$\%$ R. A. (relative abundance) } \\
\hline 224 & {$[\mathrm{M}]^{+}$.} & 58 & 67 & 83 \\
\hline 223 & {$\left[\mathrm{M}^{+} \cdot-\mathrm{H}\right]^{+}$} & 100 & 100 & 100 \\
\hline 207 & {$\left[\mathrm{M}^{+\cdot-} \cdot \mathrm{OH}\right]^{+}$} & 15 & 5 & 7 \\
\hline 205 & {$\left[\mathrm{M}^{+} \cdot-\mathrm{H}-\mathrm{H}_{2} \mathrm{O}\right]^{+}$} & 2 & 3 & 1 \\
\hline 195 & {$\left[\mathrm{M}^{+}-\mathrm{H}^{-\mathrm{CO}}\right]^{+}$or $\left[\mathrm{M}^{+}-\mathrm{COH}\right]^{+}$} & 3 & 11 & 22 \\
\hline 177 & {$\left[\mathrm{M}^{+-}-\mathrm{COH}-\mathrm{H}_{2} \mathrm{O}\right]^{+}$} & 2 & 7 & 9 \\
\hline 167 & {$\left[\mathrm{M}^{+\cdot}-\mathrm{COH}-\mathrm{CO}\right]^{+}$} & 2 & 10 & 21 \\
\hline 147 & {$\left[\mathrm{M}^{+}-\mathrm{Ph}\right]^{+}$} & 60 & 2 & 4 \\
\hline 146 & {$\left[\mathrm{M}^{+}-\mathrm{C}_{6} \mathrm{H}_{6}\right]^{+}$} & 2 & 10 & 19 \\
\hline 121 & {$\left[\mathrm{M}^{+-}-\mathrm{C}_{6} \mathrm{H}_{5} \mathrm{CH}=\mathrm{CH}\right]^{+}$} & 28 & 17 & 49 \\
\hline 120 & {$\left[\mathrm{M}^{+} \cdot-\mathrm{C}_{6} \mathrm{H}_{5} \mathrm{CH}=\mathrm{CH}_{2}\right]^{+}$} & 26 & - & - \\
\hline 104 & $\mathrm{C}_{8} \mathrm{H}_{8}^{+\cdot}$ & 10 & 4 & 2 \\
\hline 103 & $\mathrm{C}_{8} \mathrm{H}_{7}^{+}$ & 26 & 38 & 25 \\
\hline 93 & $\mathrm{C}_{6} \mathrm{H}_{4} \mathrm{OH}^{+}$ & 5 & 16 & 20 \\
\hline 92 & $\mathrm{C}_{6} \mathrm{H}_{4} \mathrm{O}^{+}$ & 15 & 2 & 3 \\
\hline 77 & $\mathrm{C}_{6} \mathrm{H}_{5}^{+}$ & 30 & 39 & 38 \\
\hline
\end{tabular}




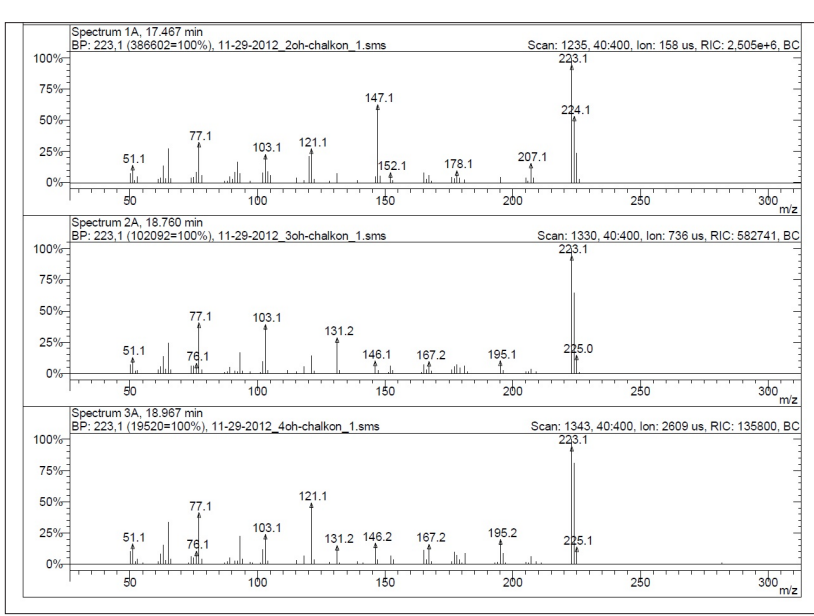

Figure 7. Mass spectra for 2'-OH-Ch, 3'-OH-Ch and 4'-OH-Ch obtained by GC/EI-MS

The characteristic features of EI fragmentation of hydroxychalcones are: loss of $\mathrm{H}, \mathrm{OH}, \mathrm{Ph}$ and $\mathrm{CHO}$ radicals (the last one is typical for phenols); complementary cleavage of single bonds, shown in the scheme below (Fig. 8):

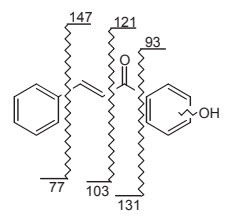

Figure 8. Single bonds cleavage in GC-MS experiments. See text for details.

The formation of an ion at $\mathrm{m} / \mathrm{z} 93$ is not favored for the ortho isomer, the bond cleavage with hydrogen transfer takes place instead, leading to the formation of an ion at $\mathrm{m} / \mathrm{z} 92$ (R. A. 15\%). Similarly, the dissociation of molecular ion to a fragment $\mathrm{m} / \mathrm{z} 121$ and complementary $\mathrm{m} / \mathrm{z} 103$ ions is intense for meta and para-hydroxychalcones, but for ortho isomer ions at $m / z 120$ and 104 are preferably formed (Table 5).

The spectra obtained for hydroxychalcones by the hard ionization EI method, as opposed to FAPA, ESI, APCI, and MALDI techniques, indicate significant fragmentation of the tested compounds. Main fragment ions are observed in all the techniques with varying the relative intensity.

\section{CONCLUSIONS}

Analysis of hydroxychalcones performed with the aid of FAPA source shows high level of similarity to those obtained by ESI and, to a lesser extent, to APCI and MALDI-TOF techniques. Comparison of the procedures and the quality of information obtained during interpretation of the spectra is presented in Table 6 .

The conclusion can be drawn that FAPA analysis of these compounds brings comparable information to the other methods applied in this study. MS/MS spectra are rich in fragments confirming the structure of compounds including strong indications for isomer identification. Additionally, FAPA allows for rapid sample analysis with no or just little sample preparation.
Table 6. Comparison and characterization of various ion sources

\begin{tabular}{|l|c|c|c|c|}
\hline \multicolumn{1}{|c|}{$\begin{array}{c}\text { Sample } \\
\text { preparation }\end{array}$} & $\begin{array}{c}\text { FAPA } \\
\text { measurement, } \\
\text { possible } \\
\text { concentration } \\
\text { of an analyte } \\
\text { in a wide range }\end{array}$ & $\begin{array}{c}\text { ESI/APCI } \\
\text { measurement, } \\
\text { concentration } \\
\text { of an analyte } \\
\text { limited to }\end{array}$ & $\begin{array}{c}\text { Mequires matrix } \\
\text { and solvent } \\
\text { for optimal } \\
\text { crystallization }\end{array}$ & $\begin{array}{c}\text { Mime } \\
\text { consuming, } \\
\text { requires } \\
\text { separation } \\
\text { of analytes }\end{array}$ \\
\hline $\begin{array}{l}\text { Presence of } \\
{\left[\begin{array}{l}\text { [M-Na }]^{+} \text {or }[M-K]^{+} \\
\text {ions in the } \\
\text { spectrum }\end{array}\right.}\end{array}$ & not observed & observed & observed & not observed \\
\hline $\begin{array}{l}\text { Presence of } \\
\text { dimers in the } \\
\text { spectrum }\end{array}$ & not observed & $\begin{array}{c}\text { sporadically } \\
\text { for high } \\
\text { concentration } \\
\text { of analyte }\end{array}$ & observed & not observed \\
\hline $\begin{array}{l}\text { Intensity of the } \\
\text { fragment ion } \\
\text { signals } \\
\text { (MS spectra) }\end{array}$ & low & low & low & high \\
\hline
\end{tabular}

\section{REFERENCES}

1. S. Alam, S. Mostahar. Studies of Antimicrobial Activity of two Synthetic 2',4',6'-trioxygenated Flavones. J. Applied Sci. 2005, 5, 327-333.

2. J. R. Dimmock, D. W. Elias, M. A. Beazely, N. M. Kandepu. Bioactivities of chalcones. Curr Med Chem. 1999, 6, 1125-49.

3. P. M. Sivakumar, T. Muthu Kumar, M. Doble. Antifungal activity, mechanism and QSAR studies on chalcones. Chem Biol Drug Des. 2009, 74, 68-79.

4. S. J. Won, C. T. Liu, L. T. Tsao, J. R. Weng, H. H. Ko, J. P. Wang, C. N. Lin. Synthetic chalcones as potential anti-inflammatory and cancer chemopreventive agents. Eur. J. Med. Chem. 2005, 40, 103-12.

5. E. C. Amor, I. M. Villaseñor, M. N. Ghayur, A. H. Gilani, M.I. Choudhary. Spasmolytic flavonoids from Syzygium samarangense (Blume) Merr. \& L.M. Perry. Z Naturforsch C. 2005, 60, 67-71.

6. J. B. Daskiewicz, F. Depeint, L. Viornery, C. Bayet, G. ComteSarrazin, G. Comte, J. M. Gee, I. T. Johnson, K. Ndjoko, K. Hostettmann, D. Barron. Effects of Flavonoids on Cell Proliferation and Caspase Activation in a Human Colonic Cell Line HT29: An SAR Study. J. Med. Chem. 2005, 48, 2790-2804.

7. F. J. Andrade, J. T. Shelley, W. C. Wetzel, M. R. Webb, G. Gamez, S. J. Ray, G.M. Hieftje. Atmospheric Pressure Chemical Ionization Source. 2. Desorption-Ionization for the Direct Analysis of Solid Compounds. Anal. Chem. 2008, 80, 2654-2663.

8. M. Smoluch, K. Labuz, E. Reszke, A. Ramsza, K. Labuz, J. Silberring. Direct analysis of methcathinone from crude reaction mixture by flowing atmospheric-pressure afterglow mass spectrometry. Rapid Commun. Mass Spectrom. 2012, 26, 1577-1580.

9. M. Smoluch, E. Reszke, A. Ramsza, J. Silberring. Development of a novel ambient glow discharge plasma source for direct analysis of organic compounds. In: Biomacromolecular Mass Spectrometry: Tips from the Bench (S. König, ed.) Nova Science Publ. 2012, ISBN: 978-1-62081-933-3.

10. Y. Tai, S. Pei, J. Wan, X. Cao, Y. Pan. Fragmentation study of protonated chalcones by atmospheric pressure chemical ionization and tandem mass spectrometry. Rapid Commun. Mass Spectrom. 2006, 20, 994-1000.

11. J. Zhang, J. S. Brodbelt. Structural characterization and isomer differentiation of chalcones by electrospray ionization tandem mass spectrometry. J Mass Spectrom. 2003, 38, 555-72. 